Article

\title{
A Spatially Highly Resolved Ground Mounted and Rooftop Potential Analysis for Photovoltaics in Austria
}

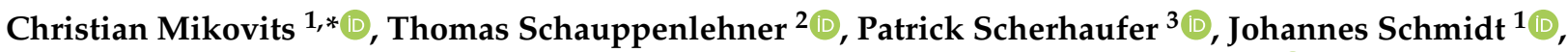 \\ Lilia Schmalzl ${ }^{4}$, Veronika Dworzak ${ }^{4}$, Nina Hampl ${ }^{4}$ and Robert Gennaro Sposato 4 (D) \\ 1 Institute for Sustainable Economic Development, University of Natural Resources and Life Sciences, \\ Feistmantelstrasse 4, 1180 Vienna, Austria; johannes.schmidt@boku.ac.at \\ 2 Institute of Landscape Development, Recreation and Conservation Planning, University of Natural Resources \\ and Life Sciences, Peter-Jordan-Straße 65, 1180 Vienna, Austria; thomas.schauppenlehner@boku.ac.at \\ 3 Institute of Forest, Environmental, and Natural Resource Policy, University of Natural Resources and Life \\ Sciences, Feistmantelstrasse 4, 1180 Vienna, Austria; patrick.scherhaufer@boku.ac.at \\ 4 Sustainable Energy Management Unit, Department of Operations, Energy, and Environmental Management, \\ Alpen-Adria-Universität, Universitätsstraße 65-67, 9020 Klagenfurt, Austria; lilia.schmalzl@aau.at (L.S.); \\ veronika.dworzak@aau.at (V.D.); nina.hampl@aau.at (N.H.); robert.sposato@aau.at (R.G.S.) \\ * Correspondence: christian.mikovits@boku.ac.at
}

\section{check for}

updates

Citation: Mikovits, C.;

Schauppenlehner, T.; Scherhaufer, P.;

Schmidt, J.; Schmalzl, L.; Dworzak, V.;

Hampl, N.; Sposato, R.G. A Spatially

Highly Resolved Ground Mounted

and Rooftop Potential Analysis

for Photovoltaics in Austria. ISPRS

Int. J. Geo-Inf. 2021, 10, 418. https://

doi.org/10.3390/ijgi10060418

Academic Editors: Wolfgang Kainz and Cristiano Fugazza

Received: 9 March 2021

Accepted: 9 June 2021

Published: 16 June 2021

Publisher's Note: MDPI stays neutral with regard to jurisdictional claims in published maps and institutional affiliations.

Copyright: (c) 2021 by the authors. Licensee MDPI, Basel, Switzerland. This article is an open access article distributed under the terms and conditions of the Creative Commons Attribution (CC BY) license (https:// creativecommons.org/licenses/by/ $4.0 /)$.

\begin{abstract}
Austria aims to meet $100 \%$ of its electricity demand from domestic renewable sources by 2030 which means, that an additional 27 TWh/a of renewable electricity generation are required, thereof $11 \mathrm{TWh} / \mathrm{a}$ from photovoltaic. While some federal states and municipalities released a solar rooftop cadastre, there is lacking knowledge on the estimation of the potential of both, ground mounted installations and rooftop modules, on a national level with a high spatial resolution. As a first, in this work data on agricultural land-use is combined with highly resolved data on buildings on a national level. Our results show significant differences between urban and rural areas, as well as between the Alpine regions and the Prealpine- and Easter Plain areas. Rooftop potential concentrates in the big urban areas, but also in densely populated areas in Lower- and Upper Austria, Styria and the Rhine valley of Vorarlberg. The ground mounted photovoltaic potential is highest in Eastern Austria. This potential is geographically consistent with the demand and allows for a production close to the consumer. In theory, the goal of meeting $11 \mathrm{TWh} / \mathrm{a}$ in 2030 can be achieved solely with the rooftop PV potential. However, considering the necessary installation efforts, the associated costs of small and dispersed production units and finally the inherent uncertainty with respect to the willingness of tens of thousands of individual households to install PV systems, installing the necessary solar PV on buildings alone is constrained.
\end{abstract}

Keywords: photovoltaic; rooftop; ground mounted; potential; Austria

\section{Introduction}

Among available renewable electricity generation technologies, solar photovoltaics (PV) is currently the fastest growing power generating technology [1]. The European Union set the goal to meet more than $30 \%$ of its final energy consumption from renewable sources by 2030 [2]. At the same time, Austria aims to generate $100 \%$ of electricity consumption from domestic renewable sources by 2030. According to the Austrian Government this leads to an additional demand for renewable electricity generation of $27 \mathrm{TWh} / \mathrm{a}$, where $11 \mathrm{TWh} / \mathrm{a}$ are to be produced from PV [3], implying a sixfold increase compared to the production in 2019 of $1.7 \mathrm{TWh} / \mathrm{a}$ [4]. The required rapid development of renewable energy in general, and PV in particular, shall be boosted by the Erneuerbare Ausbau Gesetz (Renewable Expansion Act) [5], which is expected to be ratified within 2021. The government foresees that about $4 \mathrm{TWh} / \mathrm{a}$ can be expected from rooftop installations, another $1 \mathrm{TWh} / \mathrm{a}$ from traffic areas and parking spaces, another $0.3 \mathrm{TWh} / \mathrm{a}$ from installations on landfill 
surfaces, while the majority of $5.7 \mathrm{TWh} / \mathrm{a}$ is expected to come from ground mounted PV systems [6].

Furthermore, several reports have derived long term scenarios for solar PV deployment in 2050 in Austria, ranging from 17.2 TWh/a to 111 TWh/a additional production from $\mathrm{PV}$, depending on the respective emission target.

In contrast to fossil electricity generation, solar PV produces electricity not at a few individual locations, but distributed throughout the country. Solar PV is also significantly more land-intensive than fossil generation units, in particular if the supply chain of fossil fuel production is neglected [7]. While solar PV can be generated on urban infrastructure, e.g., on rooftops, this potential is limited and costs are higher than for ground mounted PV [8]. It is therefore likely that substantial amounts of solar PV have to be deployed ground mounted and land use conflicts may arise from this infrastructure expansion. Mainly land which is currently under agricultural use would be available for ground mounted PV installations. As this would imply a competition between food, feed, and electricity production, expansion on that kind of land is discussed controversially $[9,10]$. One option for minimizing this conflict is an integrated use of agricultural land, producing both agricultural products and electricity from PV [11,12].

Solar potential databases such as EU-PVGIS (https://ec.europa.eu/jrc/en/PVGIS, accessed on 21 September 2020) [13] or renewable.ninja [14] (accessed on 21 September 2020) exist on a global scale, and provide data about solar irradiation (global, direct and diffuse) and resulting potential solar PV generation. Physical resource potentials are however not sufficient to understand how much electricity from PV can be generated instead, a multiple set of economic, ecologic and land-use criteria has to be considered

A significant amount of literature has covered the issue of determining how much renewable energy from solar PV is potentially available globally. Past scientific work and data covers either generalized numbers without spatial analyses $[15,16]$, very coarse spatial analyses as a raster [17] or analyses on national or sub-national level [18] for solar deployment in natural areas [8]. Some studies perform an analysis with a high spatial resolution, but do not account for the limitations of slope, altitude or land-use restrictions [19]. The assessment of PV potential in urban areas (rooftop PV) has been addressed by several authors either at a regional [20-22] or a local scale [23-25] at varying levels of complexity and spatial resolutions. Previous studies on the quantification of solar PV potential have to a large extent focused on rooftop PV [13,20,26-28] some of which have been built on a very coarse spatial resolution and thus provide little insights with respect to the precise distribution of the potential. The focus on rooftop solar PV also implies that open-space solar PV potential analyses are scarce [29] and often do not focus on the issue of spatial distribution to support PV site assessment.

For Austria, only few studies have been conducted to assess the ground mounted PV potential, i.e. Schmidt et al. show high resolution numbers on regional autarky for a small region in Northern Austria [30], while Brudermann et al. [31] present generalized numbers on PV on agricultural areas with a focus on the willingness to adopt. For rooftop PV, Simoes et al. [32] show calculations with technical potentials adapted from the JRC-IET Times Model. Fechner [6] gives a comprehensive literature overview on PV in Austria (in German) citing generalized numbers from previous studies: Defaix et al. [33] presented rough, generalized numbers for the whole EU which were downscaled for Austria, Seidl [34] calculated numbers for Vienna which were scaled to cover whole Austria, Kjellsson [35] show a single number for rooftop PV potential for Austria and Streicher et al. [36] also presented generalized numbers in their report.

Rooftop PV cadastres exist for six federal states in Austria: Burgenland (http:// www.eubgld.at/index.php?id=1893, accessed on 15 November 2020), Carinthia (https:/ / gis.ktn.gv.at/webgisviewer/atlas-mobile/map/Energie, accessed on 15 November 2020), Salzburg (https:/ / www.salzburg.gv.at/sagismobile/sagisonline, accessed on 15 November 2020), Styria (https: / / gis.stmk.gv.at/atlas, accessed on 15 November 2020), Tyrol (https: / / www.tirolsolar.at, accessed on 15 November 2020) and Vienna (https://www.wien. 
gv.at/stadtentwicklung/stadtvermessung/geodaten/solar/index.html, accessed on 15 November 2020), and additionally for the cities of Linz (https:/ / webgis.linz.at/rpweb/ Solarpotential.aspx, accessed on 15 on November 2020), St. Pölten (http:/ / st-poelten.map2 web.eu/, accessed on 15 November 2020), Baden (http:/ / gis.stadtgemeinde-baden.at/, accessed on 15 November 2020) and Feldkirch (https:/ / swap.feldkirch.net/s/z6tAKyB7 FbYUkra, accessed on 15 November 2020). Nevertheless, the data provided is usually not downloadable, but can only be viewed online.

In our analysis, we address three research gaps: (i) we conduct the first analysis of rooftop and ground mounted PV potentials conjointly, for the whole of Austria at very high spatial resolution and put it into the context of current policy goals, to address the competition between the two and to support the design of expansion scenarios in Austria. (ii) For ground mounted PV, we differentiate results by category of agricultural land, thus allowing to better understand the potentials for integrating agricultural production and PV generation. (iii) We conduct the analysis with a newly developed tool, which relies only on open data only and is made available as open access. The analysis therefore could easily be replicated for other countries, given the availability of buildings data and rasterized data on land-use and relief.

\section{Materials and Methods}

\subsection{Model Framework}

A framework to automatically read land-use and relief data, filter by land use codes, altitude, and slope and further download solar PV data was developed and can be found online: https:/ / github.com/inwe-boku/pvaustria2021 (accessed on 10 June 2021). The framework is able to fetch Solar Data automatically from a defined source, and join, manipulate and alter it using various spatial methods.

\subsubsection{Ground Mounted Photovoltaics}

Figure 1 shows a flow chart of our data processing framework which generates the output for ground mounted PV data: The input of land-use data and elevation is expected to be in raster format, while the aggregation regions are expected to be in a vector polygon format. The given sampling resolution is used to generate a vector grid used for sampling from the raster data. Next, each of the grid points is assigned with values for land use and, if provided, also altitude and slope. Each of the grid points samples not the whole area a grid point covers, but, for performance reasons, either one, five or thirteen values (see Figure 2) and depending on the input the most frequent value or the mean value is chosen for the grid point. The additional samples were introduced to prevent single sampling errors when probing raster values from land-use, altitude or slope, e.g., to prevent that one small shrub patch in the middle of a big field is assumed to represent the whole grid point. Altitude and slope are filtered using the $l t$ and le operators, where for land-use the values are compared with a set of values from a list. For each of the allowed grid points, PV data is fetched from PVGIS and processed. Monthly, quarterly and yearly summaries are stored for each grid point with all values as attributes. Consequently, all points are assigned to the provided regional polygons (i.e., municipalities) and summarizing statistics are calculated. 


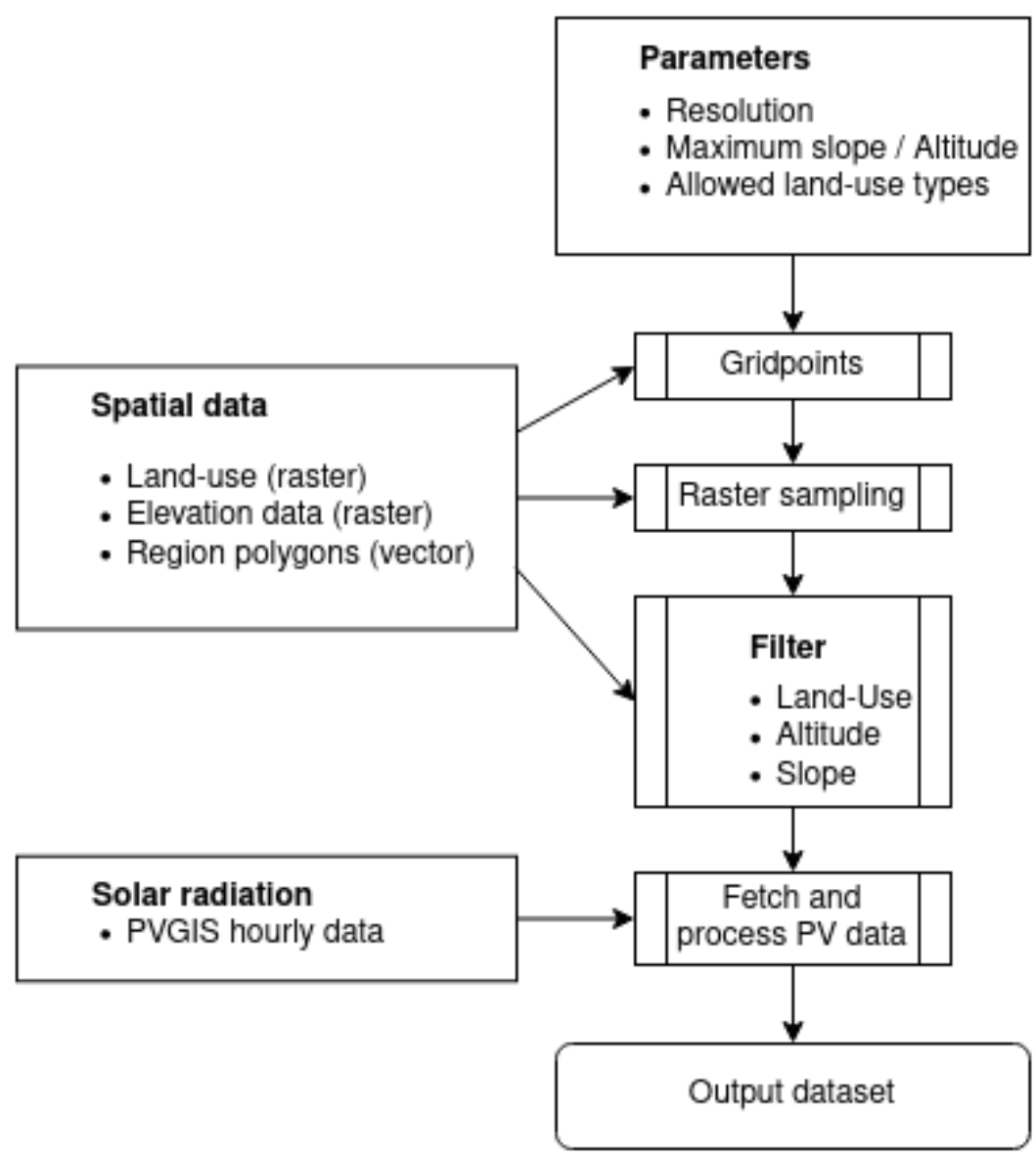

Figure 1. Flow chart for the generation of ground mounted PV data.

a)

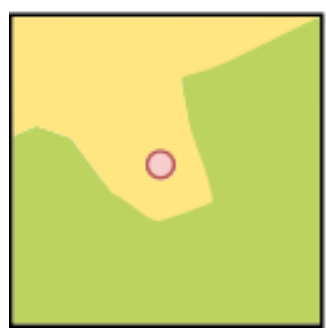

b)

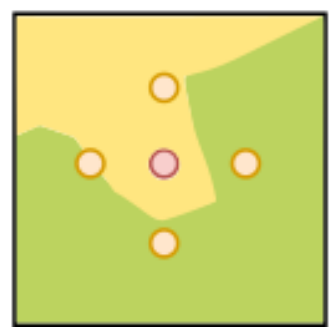

c)

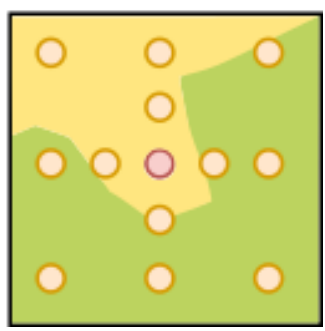

Figure 2. Raster sampling methods: the outline shows the vector grid outline, red is the grid center, in yellow additional sampling points depending on the chosen method are shown, (a) shows the sampling of one value within a gridpoint, (b) of 5 values and (c) of 13 values.

\subsubsection{Rooftop Photovoltaics}

To calculate the rooftop potential for each building PV data for random buildings within a geographical area, e.g., municipality, PV data is fetched from PVGIS. Each building is assigned with values from the nearest building with these reference values: The software framework allows to use any spatial data generated from available vector buildings data, which also means the usage of buildings data from open data sources, i.e., OpenStreetMap. First, the footprint area of each building is calculated and then grouped by region, in this case the municipalities. In the next step, from each regional dataset a user-defined number of buildings is sampled randomly, to minimize the volume of solar radiation data, reduce load on the server and also to limit download data and time significantly, while not losing much evidence in results. Here, the following Equation (1) to determine the number of 
sampled buildings was used, where $n_{s}$ is the number of sample buildings and $n_{b}$ is the number of buildings within one region:

$$
n_{s}=\min \left(n_{b}, 3 \cdot n_{b}^{0.4}\right)
$$

This formula was chosen to ensure a high sampling rate with a low number of buildings and a lower percentage with large number of buildings within one area, i.e., a number of 10 buildings translates to a sample number of 8,100 buildings to 19, 1,000 to 48 , and 10,000 to 119 . For each sampled building, PV data is fetched from PVGIS, processed and further linked with the nearest buildings within the region. An example how a sampling of buildings looks like is shown in Figure 3. Finally the data is stored and aggregated by region for further processing.

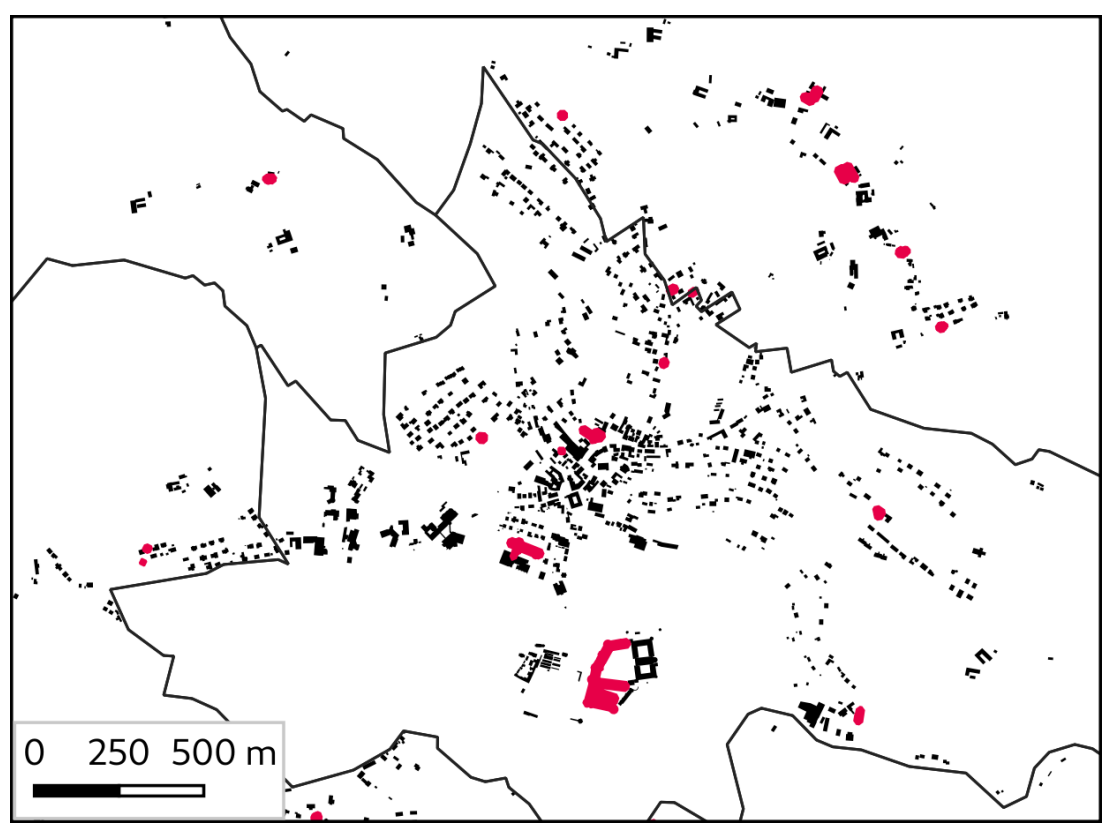

Figure 3. Example for sampling buildings.

\subsection{Input Data}

\subsubsection{Solar Radiation}

In this work we used hourly data through the non-interactive service API of the EU Science Hub-PV-GIS provided by the EU JRC (https:/ / ec.europa.eu/jrc/en/PVGIS/ docs/noninteractive, accessed on 1 July 2020). This service provides high resolution solar radiation data (for this work PVGIS-SARAH with $5 \mathrm{~km}$ ) resolution in combination with a global digital ground model $(90 \mathrm{~m})$ to account for shadows from terrain. The data was fetched, assuming that PV panels are southward facing with an inclination of $35^{\circ}$. We further assume crystal silicon based PV technology and overall system losses of $14 \%$, to account for losses from cabling, power inverters and also dirt [37].

\subsubsection{Spatial Data}

We assessed land-use with a combined dataset, consisting of the EU Integrated Administration and Control System (IACS) vector data from 2018 [38] and a nation-wide Sentinel-2 based land cover raster dataset from 2016 with a $10 \mathrm{~m}$ resolution [39]. Both datasets are available in the open government data (ODG) catalog of Austria (https:/ / data.gv.at, accessed on 20 June 2020). The IACS data contains agricultural areas and covers the gross of all agricultural parcels in Austria. The Sentinel-2 land cover raster dataset contains land cover classes such as forest, water surfaces, sealed areas or buildings. Both datasets were combined by merging both data sources using the mosaicing method from SAGA 
GIS [40]. For slope data calculation within the model framework, the freely available digital elevation model with a resolution of $10 \mathrm{~m}$ is used [41].

For the assessment of building footprints and the available rooftop area, we processed official cadastral vector data extracted from https: / / basemap.at (accessed on 20 June 2020) for rooftop PV. The data can be considered as complete and a total of 4.8 million vector tiles with a total area of $784 \mathrm{~km}^{2}$ have been processed.

\subsubsection{Parameters}

Input parameters for the varying scenarios were chosen as shown in Table 1, land-use and rooftop scenarios are presented in Table 2. The rooftop value defines the relation of the building footprint to usable rooftop surface for PV usage. These values are adopted from the work of Bergamasco et al. [20] and presented in Table 3. For rooftop solar PV we consider one out of the two pitches of a typical roof, the pitch facing south (or partially south as in south-east or south-west) is preferred for installations, while the pitches facing north is usually not considered for PV. This leads to a decrease of roof surface available per building of $60 \%\left(C_{R T}\right)$. Furthermore, we consider the space already occupied by chimneys or windows with a feature coefficient of $65 \%\left(C_{F T}\right)$. To prevent self-shadowing of the modules, a coefficient of $55 \%$ is applied $\left(C_{C V}\right)$. We define a coefficient which represents the roof availability in terms of structural conditions with $75 \%\left(C_{S C}\right)$ and historic preservation with $95 \%\left(C_{H P}\right)$. The product of all coefficients results in the total building footprint coefficient of $15.2 \%\left(C_{t o t}\right)$.

Table 1. PV calculation parameters.

\begin{tabular}{cc}
\hline Parameter & Value \\
\hline grid resolution & $250 \mathrm{~m}$ \\
maximum altitude & $1950 \mathrm{~m}$ \\
maximum slope & $35 \%$ \\
ground mounted density & $20 \mathrm{~m}^{2} / \mathrm{kWp}$ \\
rooftop density & $8 \mathrm{~m}^{2} / \mathrm{kWp}$ \\
\hline
\end{tabular}

Table 2. Modelled ground mounted PV land-use scenarios.

\begin{tabular}{cc}
\hline Scenario & PV Land-Use \\
\hline All Open & Agricultural fields and pastures \\
Crops E Vegetables & Cropland \& vegetable fields \\
Pastures & Pastures and greenland \\
Cereals & Only cereal cropland \\
Vegetables & Only vegetable fields \\
\hline
\end{tabular}

Table 3. Coefficients for rooftop assessment.

\begin{tabular}{ccc}
\hline Coefficient & Value & Description \\
\hline$C_{R T}$ & 0.60 & rooftop: pitches \\
$C_{F T}$ & 0.65 & features: chimneys/windows \\
$C_{C V}$ & 0.55 & self-shading \\
$C_{S C}$ & 0.75 & structural conditions \\
$C_{H P}$ & 0.95 & historic preservation \\
\hline$C_{t o t}$ & 0.15 & total \\
\hline
\end{tabular}




\subsection{Goals}

Several reports have analyzed long term scenarios for solar PV deployment in 2050. The Austrian federal environmental agency (Umweltbundesamt) reported additional 21.7 TWh/a (23.4 TWh/a in total) [42] reducing $\mathrm{CO}_{2}$ emissions to $20 \mathrm{Mt} \mathrm{a}^{-1}$, which means a reduction by $78 \%$, a joint report of NGOs calculated $31.3 \mathrm{TWh} / \mathrm{a}$ (33 TWh/a in total) [43] for a reduction of emission by $90 \%$ including industry. Auer et al. [44] simulated additional need for up to $48.3 \mathrm{TWh} / \mathrm{a}$ (50.0 TWh/a in total) for a complete decarbonization and Jacobsen et al. [45] suggest that a $100 \%$ (zero emission, including industry) renewable system in 2050 would need an additional PV production of $109.3 \mathrm{TWh} / \mathrm{a}$ (111 TWh/a in total).

\section{Results}

\subsection{Ground Mounted Photovoltaics}

Results show that the physical potential for ground mounted PV in Austria is as high as $1614 \mathrm{TWh} / \mathrm{a}$, with significant differences in potential between the alpine areas and the pre-alpine areas spanning in an arc from the north, over the eastern plains to the south. The alpine mountain range is predominantly defined by forests and not-suitable high-elevation and/or steep slope areas, while the valley bottoms are sometimes characterized by low average solar radiation due to relief shading effects. Figure 4 shows the PV potential in Austria for all ground mounted areas with only a few restrictions (see Section 2.2.3) in effect, where the purple line indicates the border of the alpine area [46]. The five different spatial scenarios presented below are derived from this data and present the potential depending on predominant land-use and agricultural type. All Open land (a) shows huge potential throughout Austria, where scenario Crops \& Vegetables (b) shows a reduction by more than $50 \%$, Pastures (c) and Cereals (d) a reduction by more than $60 \%$, and finally Vegetables (e) constitutes only $10 \%$ of the All Open potential. Figure 5 shows the PV energy density in $\mathrm{kWh} \mathrm{ha}^{-1}$ summarized for Austria's municipalities area and for all five analyzed land-use scenarios. The numbers for each of the scenarios are presented in Table 4. For each of the scenarios the number of grid points, the area, the median, and mean value of electrical energy production, the sum (total) potential of all areas within this scenario are presented.

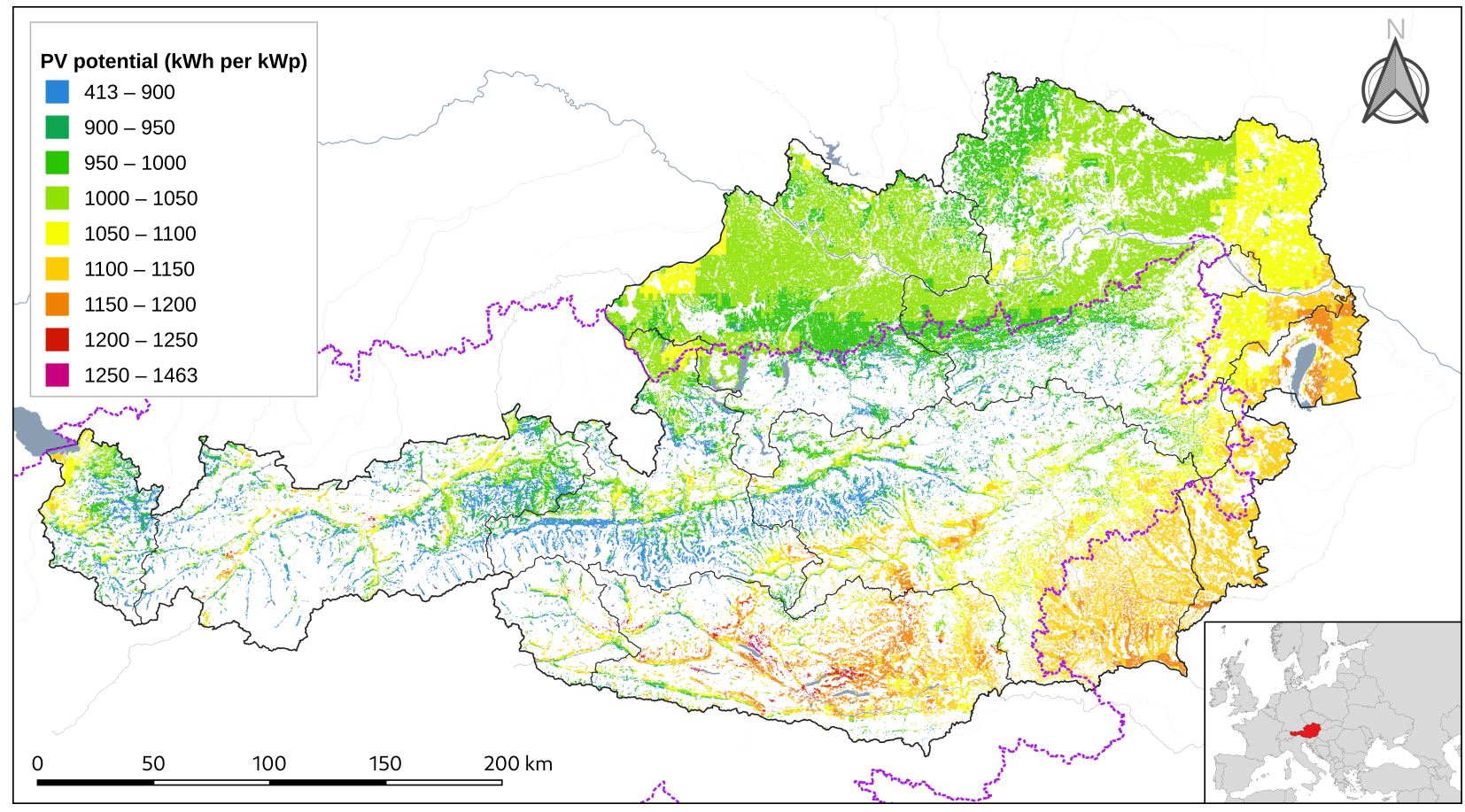

Figure 4. Austrian ground-mounted PV potential overview. 


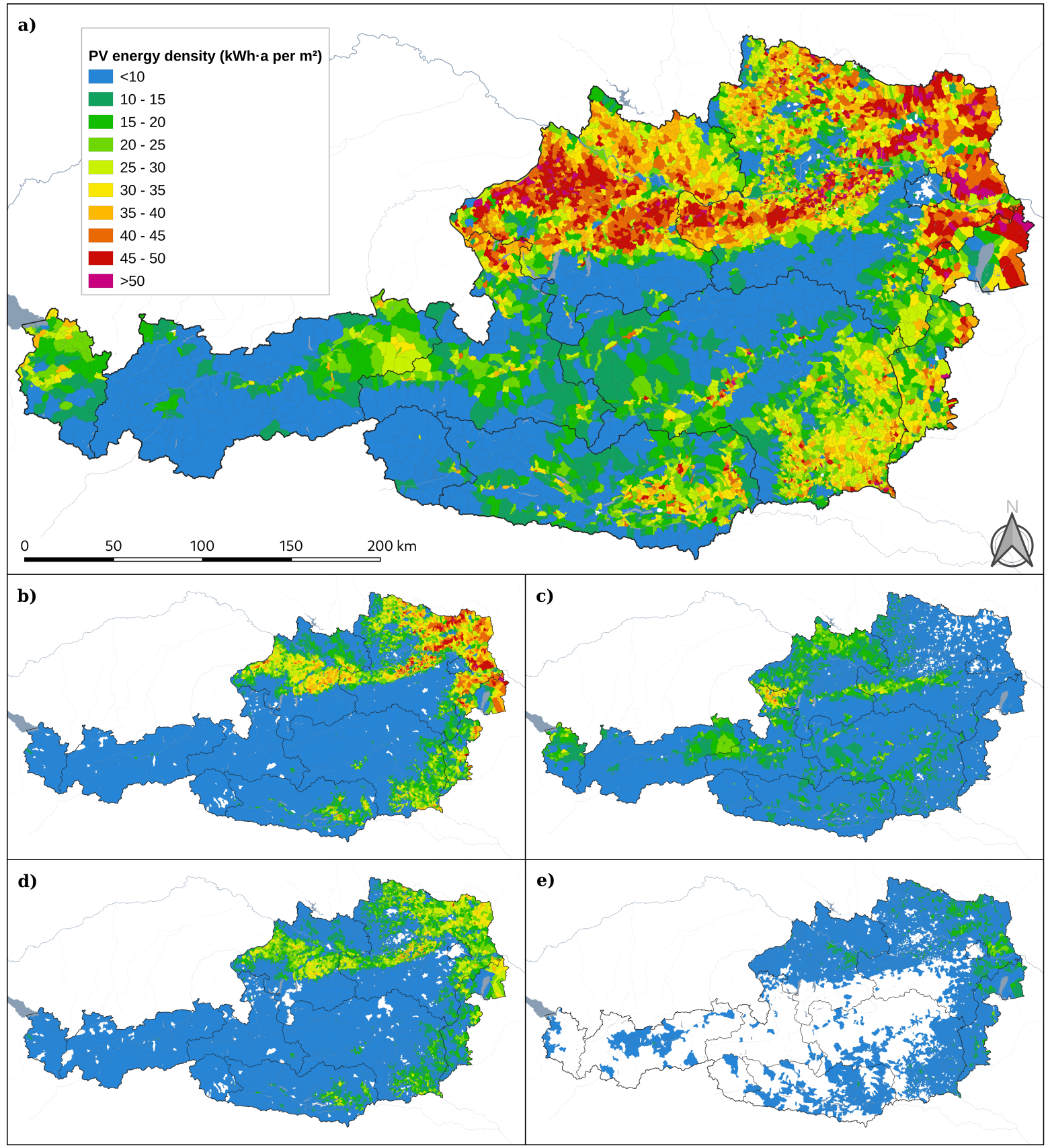

Figure 5. Austrian ground mounted PV energy density in $\mathrm{kW} \mathrm{h} \mathrm{m}^{-2}$ for the whole cadastral municipality, spatial scenarios: (a) All Open, (b) Crops \& Vegetables, (c) Pastures, (d) Cereals, (e) Vegetables.

Table 4. Ground mounted PV land-use results.

\begin{tabular}{|c|c|c|c|c|c|}
\hline Scenario & Grid Points & $\begin{array}{c}\text { Area } \\
\left(\mathrm{km}^{2}\right)\end{array}$ & $\begin{array}{c}\text { Median } \\
(\mathrm{kWh} / \mathrm{kWp})\end{array}$ & 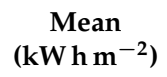 & $\begin{array}{l}\text { Total Potential } \\
\text { (TWh/a) }\end{array}$ \\
\hline Austria & $1,336,286$ & 83,518 & - & - & - \\
\hline All Open & 505,794 & 31,612 & 1029 & 51.06 & 1614 \\
\hline $\begin{array}{c}\text { Crops } \mathcal{E} \\
\text { Vegetables }\end{array}$ & 230,142 & 14,384 & 1042 & 52.34 & 753 \\
\hline Pastures & 194,179 & 12,136 & 1011 & 49.75 & 604 \\
\hline Cereals & 163,321 & 10,208 & 1038 & 52.17 & 533 \\
\hline Vegetables & 50,120 & 3133 & 1052 & 52.65 & 165 \\
\hline
\end{tabular}




\subsection{Rooftop Photovoltaics}

Rooftop PV in general shows a high potential all over Austria, again very similar to ground mounted solar PV with a higher potential in the East and outside the alpine areas. Figure 6 displays the PV potential of rooftops in Austria on a $500 \mathrm{~m} \times 500 \mathrm{~m}$ raster. Areas with high population density are clearly shown as peaks (red), but also medium density areas generally present a high potential over a large area. Low potential can only be seen in inner-alpine valleys where the relief is responsible for less PV output, especially in winter. In total, we derive a PV rooftop potential of $16.11 \mathrm{TWh} /$ a of which $35.33 \%$ can be produced during the summer season (June, July, August) and $12.28 \%$ are potentially produced in the winter months (December, January, February). Half of the electrical energy is being produced during the six remaining months.

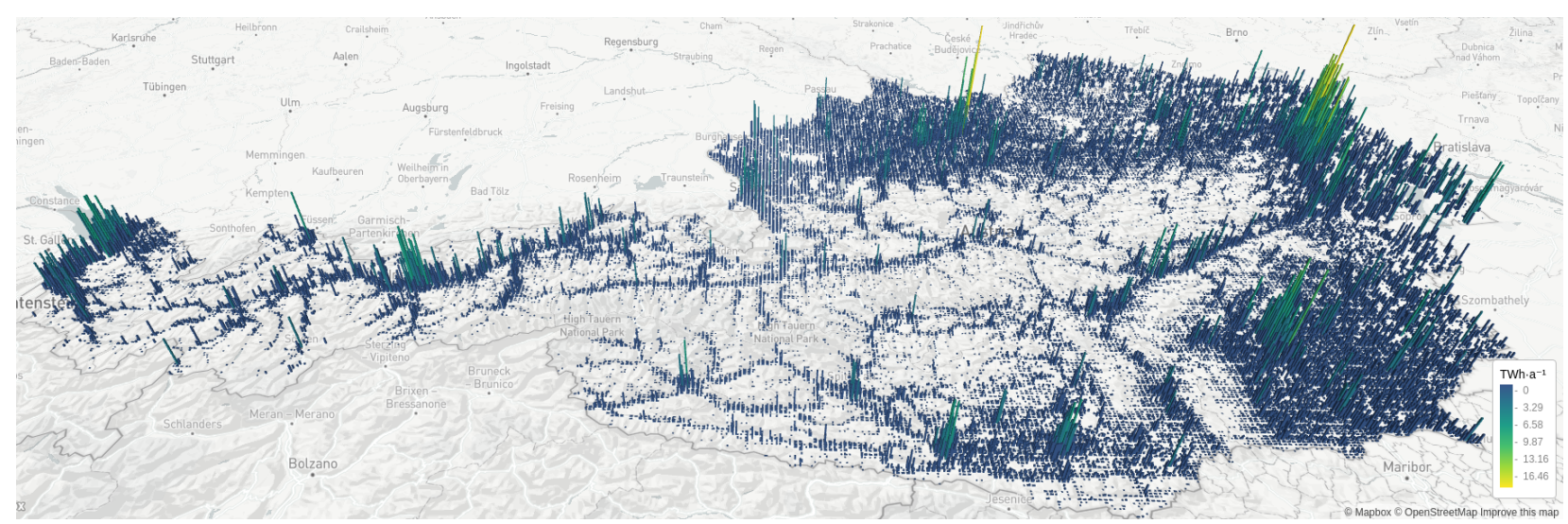

Figure 6. Austrian rooftop PV energy density on a $500 \mathrm{~m}$ raster.

Figure 7 presents the rooftop PV potential for each municipality in $\mathrm{kW} \mathrm{ha}^{-1}$, calculated with (a) all year values, with (b) values from summer months (June, July, August) and (c) values from the winter months (November, December, January). As already presented in Figure 4 high density urban areas show a high potential in rooftop solar PV, while less populated areas show lower values. Some areas have been highlighted as they showcase regional differences of Austria: (i) Rhine valley: densely populated, low rise, separated buildings, (ii) Tyrol: large municipalities (iii) Upper Austria: dense population throughout the federal state (iv) Waldviertel: low population density, small municipalities (v) Vienna: largest metro area in Austria, densely populated (vi) Seewinkel: large municipalities, dense villages (vii) Graz: second-largest metro area in Austria.

Figure 8 shows the cumulative PV potential by cumulative number of buildings sorted by footprint area (large to small). It can be seen that the $11 \mathrm{TWh} / \mathrm{a}$ goal can be reached by utilizing the rooftop potential of only $28 \%$ of buildings (all buildings larger than $210 \mathrm{~m}^{2}$, if only taking into account the largest, while reaching feasible $4 \mathrm{TWh} / \mathrm{a}$ [6] to $4.5 \mathrm{TWh} / \mathrm{a}$ (shown in Section 3.3 within the next 10 years would only need $3 \%$ to $4 \%$ of buildings (all buildings with a footprint larger than $880 \mathrm{~m}^{2}$ ). Even though the number of buildings increases with decreasing footprint sizes, the potential from these buildings flattens the curve. 


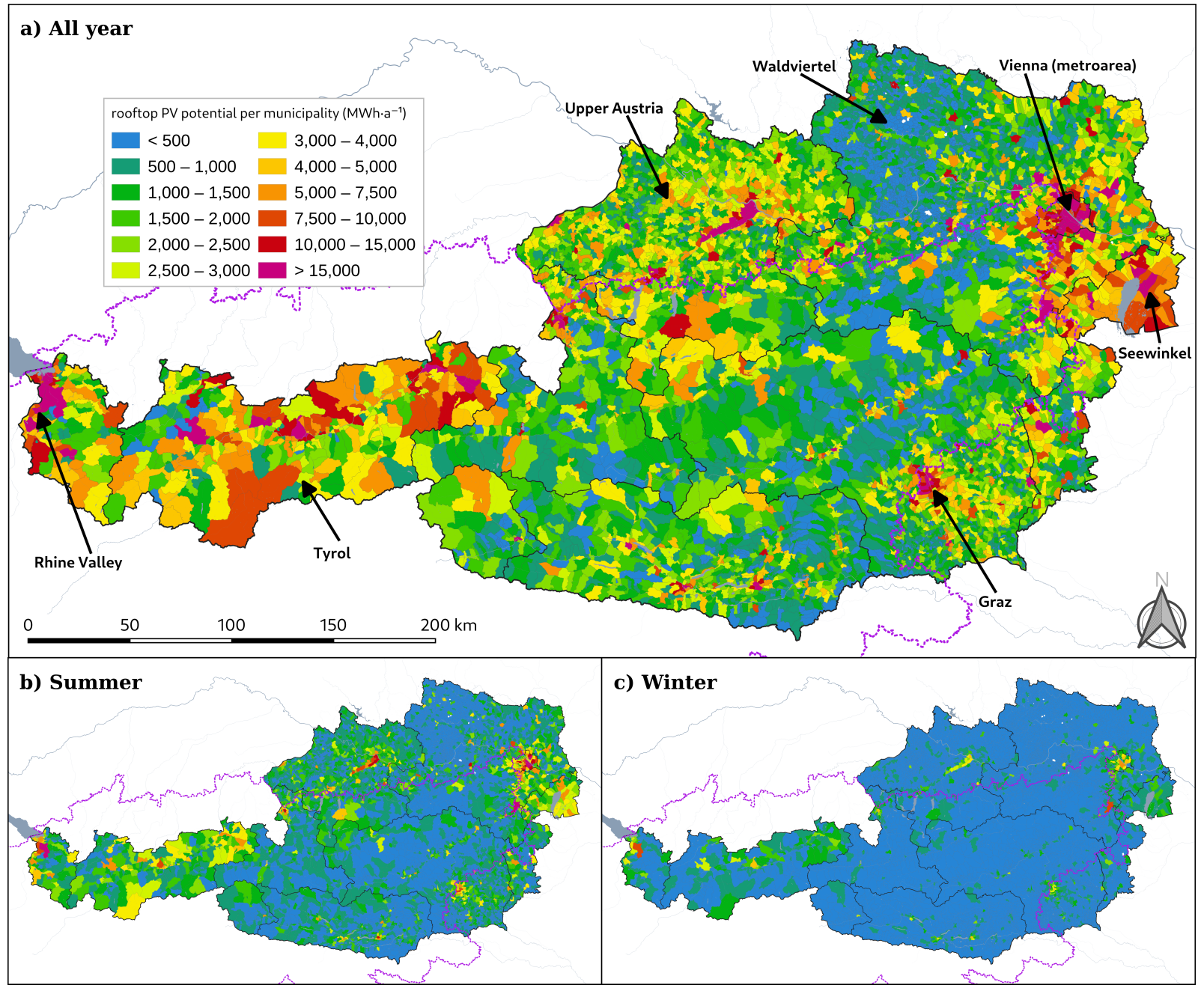

Figure 7. Austrian rooftop PV energy density for each cadastral municipality.

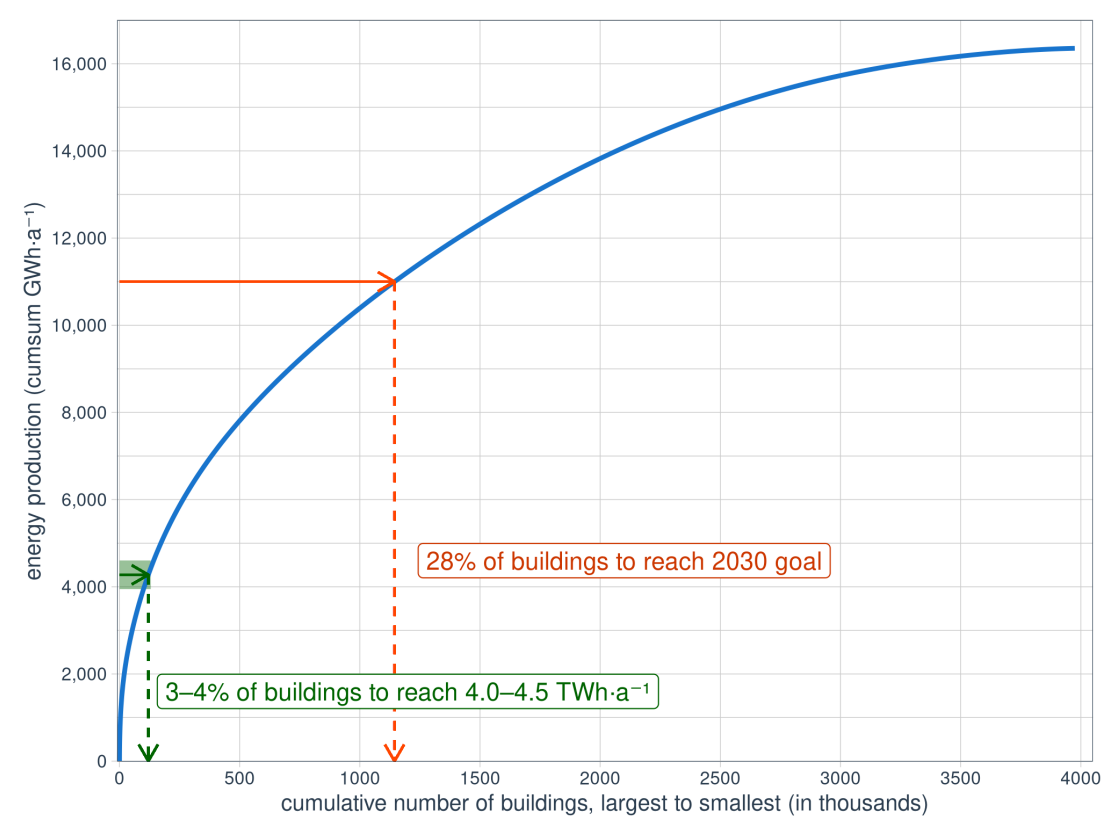

Figure 8. Austrian rooftop PV potential (y-axis) in relation to the number of buildings ( $x$-axis, buildings are sorted by footprint size from large to small. 


\subsection{Goals in Relation}

For further analysis we put the derived numbers in relation with the Figures of reports and publications presented in Section 2.3. Taking the results for rooftop PV with a total technical potential of $16.1 \mathrm{TWh} / \mathrm{a}$ and a maximum yearly installed additional capacity of $250 \mathrm{MWp}$ [47], we extrapolate a production of additional $4.5 \mathrm{TWh} / \mathrm{a}$ by 2030 and $10 \mathrm{TWh} / \mathrm{a}$ by 2050 . Using these numbers we are able to roughly estimate the need of ground mounted PV. Table 5 shows the total goal in TWh/a of additional PV output according to the corresponding studies and annual Figures of 2030 and 2050. The demand area shows the area needed to reach the goal after subtracting the assumed rooftop PV potential. Below we show the percentage of area needed for each scenario we presented in Table 4 . We can observe that especially the area needed to reach the highest calculated goal of $111.0 \mathrm{TWh} / \mathrm{a}$ [45] would consume almost 2000 ha of agricultural land. Hence, the effort to put PV on rooftops and on already sealed or used surfaces, such as parking spaces or landfill sites should be fostered. Additionally, the opportunity of installing PV as agrivoltaics can further lessen the need for pure ground mounted PV installations.

Table 5. 2030 and 2050 goals in relation to the result numbers.

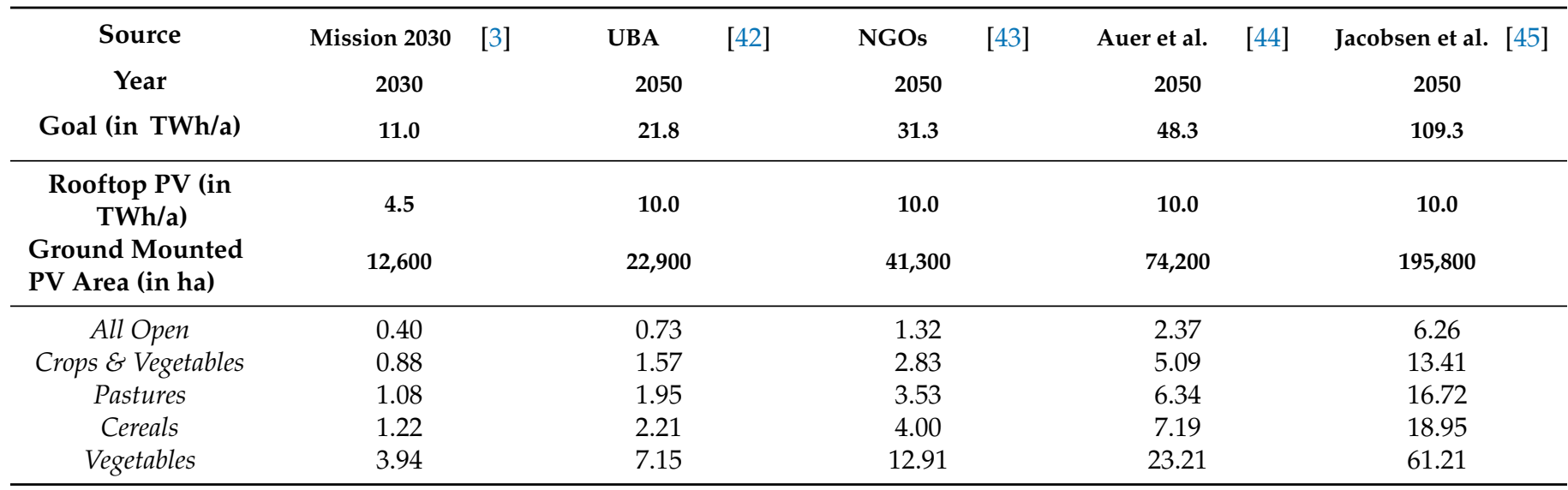

All results presented in this article can be found online on zenodo for further usage and analysis [48].

\section{Discussion}

\subsection{Ground Mounted Photovoltaics}

For open-space PV, five different land-use analyses have been presented. It has been shown that the solar energy potential over the whole country is up to $1614 \mathrm{TWh} / \mathrm{a}$, according to the All Open scenario. In this scenario, to reach the goal of an additional $11 \mathrm{TWh} / \mathrm{a}$ by 2030 , only $0.68 \%$ of the available area has to be utilized for ground mounted solar PV. Despite the relatively low percentage, this still translates to an area of about $215 \mathrm{~km}^{2}$, which will be withdrawn from agricultural production. The main regions can be found in the North-East. In this domain spatially explicit data is crucial for a comprehensive planning process. To mitigate the trade-off between agricultural production and electricity generation, both forms of production could be combined using agrivoltaic systems, allowing for the simultaneous production of food and electricity. These areas in the north-east may benefit from agrivoltaics as they are affected by high temperatures and droughts and are likely to face yield losses due to climate change in the future [49,50]. In this respect, alpine areas (South and West of the purple line) as opposed to the areas outside the alpine arc present an interesting case for advancing efforts to expand PV. Within the alps, mainly pastures are available for ground mounted PV, and despite the fact that large parts of these areas cannot be considered due to steep slopes or high altitudes they represent a very promising environment as they yield a high solar irradiation potential [51], the high altitude provides a better performance of PV panels because of lower operation tempera- 
tures, less fog and higher snow-reflection rates [52] and could attenuate seasonality. Also, investigating ground mounted PV in alpine areas would help include another important perspectives, well worth of future scholarly endeavors, competing interests and the serious conflicts they can trigger, especially with regard to the preservation of alpine ecosystems are apparent [53]. The inherent target conflict between conservation, climate protection and the development of renewable energy in sensible areas [54], such as alpine pastures, can seem daunting, but these environments might also offer a tale of how win-win solutions can be achieved. The ecological impacts of ground mounted PV are not fully understood yet, and only little literature exists with results which do not yet offer a definite conclusion on effects [55] or even pointing to positive effects on biodiversity [56] and even larger knowledge gaps are there for agrivoltaics. This opens a research avenue which could focus on less attractive areas like marginal yield areas, in particular alpine pastures or hillside locations of more than $20^{\circ}$ inclination, where agricultural management is or will be unprofitable and therefore is of no or low interest. In this context the possibility of energy production in these areas, which would otherwise be abandoned, can also aim at conserving biodiversity and should therefore be scrutinized with respect to conservational costs and benefits.

\subsection{Rooftop Photovoltaics}

Our results indicate that the goal of $11 \mathrm{TWh} / \mathrm{a}$ can be reached with rooftop PV alone, even with a factor as low as $15 \%$ of building footprint in relation to PV rooftop area. Although this Figure might appear underwhelming, one should not underestimate the considerable efforts necessary to achieve such an expansion. It is evident that the willingness and capabilities of households and building owners to install PV on more than $2 / 3$ of all eligible buildings in Austria until 2030 represents an immense challenge. This in turn dictates that ground-mounted solar PV will have to contribute in some way. However, to maximize the yield from rooftop PV however, both in terms of availability and the aforementioned issues regarding individual-level decision-making, research results can be taken into consideration. Unsurprisingly the urban centers and settlement agglomerations show the highest rooftop PV potential density. As shown the goal of $11 \mathrm{TWh} / \mathrm{a}$ can be reached by only utilizing $28 \%$ of buildings, if using the largest. This minimizes the effort for planning installations and reduces the amount of individual decisions. Additionally, larger buildings often offer better roof conditions and circumstances for installations, i.e., flat roofs, less or no chimneys, or better grid connections. From these insights it becomes evident that efforts to expand rooftop PV should not focus on single family homes or buildings below a footprint area of less than $150 \mathrm{~m}^{2}$. The total potential on these buildings is relatively small and at the same time the reliance on decisions from a multitude of individual owners and other involved individuals would quite drastically increase the efforts and costs associated with this type of installations. On bigger buildings, such as supermarkets, retail or industry facilities with more than $300 \mathrm{~m}^{2}$ of building footprint the installation of PV should be prioritized, as this would mean less individual decisions, less effort due to bigger installations and in general a higher usage of the existing potential on rooftops. The spatial distribution of both ground mounted and rooftop PV is in line with big urban and industrial centers, meaning no or only few adaptions to the existing power grid are necessary, if anticipatory planning takes place. In summary, the paper shows that expanding PV will need rooftop as well as ground-mounted PV systems, in particular in the long-term. The renewable energy transitions, if conducted in a decentralized way, is driven by many individual decisions on installing generation equipment. At the same time, opposition, and a lack of social acceptance on the individual or community level may impede expansion of larger scale ground-mounted PV systems.

\section{Conclusions}

We have introduced an open methodology for the assessment of the PV solar energy potential in Austria. The methodology proposed is accomplished through the evaluation of potential land-use areas for ground mounted PV and the building footprint for rooftop PV 
systems. The procedure presented here only requires freely accessible data and is therefore easily reproducible for other countries.

With particular attention to Austria's 2030 targets, this paper offers three principal insights: (i) In theory the goal of meeting $11 \mathrm{TWh} / \mathrm{a}$ in 2030 can be achieved with rooftop PV potential alone. However, the technical potential is only slightly higher than the expansion goal. Therefore, considering the necessary installation efforts, the associated costs of small and dispersed production units and finally the inherent uncertainty with respect to the willingness of tens of thousands of individual households to install PV systems, installing the necessary solar PV on buildings alone may be severely constrained. (ii) At the same time, the needs for an expansion of PV generation for a full decarbonization of the Austrian economy until 2050 is an order of magnitude higher than the 2030 goal, with an additional energy demand from solar PV of 21.8 TWh/a to $109.3 \mathrm{TWh} / \mathrm{a}$. Therefore, in the long term, installations of ground mounted PV will be necessary. (iii) Concentrating the realization of rooftop installations on larger buildings with a footprint of more than $210 \mathrm{~m}^{2}$ allows to attain $67 \%$ of the total potential and reach the goal of $11 \mathrm{TWh} / \mathrm{a}$. Further research should explore if a focus on this large buildings is a way of quickening the deployment of roof-top PV by decreasing the number of single choices by owners (see Figure 8), the installation costs, and both technical and administrative efforts.

Author Contributions: Conceptualization, Christian Mikovits; Data curation, Christian Mikovits and Thomas Schauppenlehner; Formal analysis, Christian Mikovits; Funding acquisition, Nina Hampl and Robert Gennaro Sposato; Investigation, Christian Mikovits; Methodology, Christian Mikovits; Project administration, Nina Hampl and Robert Gennaro Sposato; Resources, Christian Mikovits, Thomas Schauppenlehner, Patrick Scherhaufer and Lilia Schmalzl; Software, Christian Mikovits and Veronika Dworzak; Supervision, Johannes Schmidt and Robert Gennaro Sposato; Validation, Christian Mikovits and Johannes Schmidt; Visualization, Christian Mikovits; Writing—original draft, Christian Mikovits; Writing_-review \& editing, Christian Mikovits, Patrick Scherhaufer, Johannes Schmidt and Robert Gennaro Sposato. All authors have read and agreed to the published version of the manuscript.

Funding: This research was funded by ACRP projects "ReTour", grant number B769983, "PA ${ }^{3} \mathrm{C}^{3}$ ", grant number KR19AC0K17594, and we also gratefully acknowledge support from the European Research Council ("reFUEL" ERC2017-STG 758149).

Institutional Review Board Statement: Not applicable.

Informed Consent Statement: Not applicable.

Data Availability Statement: All results presented in this article can be found online on Zenodo for further usage and analysis: https:/ / doi.org/10.5281/zenodo.4475469 (accessed on 10 June 2021).

Conflicts of Interest: The authors declare no conflict of interest.

\section{References}

1. REN21. Renewables 2020 Global Status Report; Technical Report; REN21 Secretariat: Paris, France, 2020.

2. The European Parliament and the Council of the European Union. Directive (Eu) 2018/2001 of the European Parliament and of the Council; The European Parliament and the Council of the European Union: Brussels, Belgium, 2018.

3. Federal Ministry for Innovation. \#mission 2030-Austrian Climate and Energy Strategy; Vienna, Austria, 2018. Available online: https:/ / www.bundeskanzleramt.gv.at/dam/jcr:903d5cf5-c3ac-47b6-871c-c83eae34b273/20_18_beilagen_nb.pdf (accessed on 10 June 2021).

4. e-Control. Ökostrombericht 2020; Technical Report; e-Control: Vienna, Austria, 2020.

5. Österreichischer Nationalrat. Bundesgesetz über den Ausbau von Energie aus Erneuerbaren Quellen (Erneuerbaren-Ausbau-GesetzEAG) (Draft); Republic of Austria: Vienna, Austria, 2020. Available online: https:/ /www.bmk.gv.at/dam/jcr:f1017b8b-f77b-4613 -aa79-e20a7786dee2/EAG-entwurf.pdf (accessed on 10 June 2021).

6. Fechner, H. Ermittlung des Flächenpotentials für den Photovoltaik-Ausbau in Österreich: Welche Flächenkategorien sind für die Erschließung von Besonderer Bedeutung, um das Ökostromziel Realisieren zu können; Endbericht: Vienna, Austria, 2020; p. 69.

7. Ristic, B.; Mahlooji, M.; Gaudard, L.; Madani, K. The relative aggregate footprint of electricity generation technologies in the European Union (EU): A system of systems approach. Resour. Conserv. Recycl. 2019, 143, 282-290. [CrossRef] 
8. Ruiz, P.; Nijs, W.; Tarvydas, D.; Sgobbi, A.; Zucker, A.; Pilli, R.; Jonsson, R.; Camia, A.; Thiel, C.; Hoyer-Klick, C.; et al. ENSPRESO-An open, EU-28 wide, transparent and coherent database of wind, solar and biomass energy potentials. Energy Strategy Rev. 2019, 26, 100379. [CrossRef]

9. Sacchelli, S.; Garegnani, G.; Geri, F.; Grilli, G.; Paletto, A.; Zambelli, P.; Ciolli, M.; Vettorato, D. Trade-off between photovoltaic systems installation and agricultural practices on arable lands: An environmental and socio-economic impact analysis for Italy. Land Use Policy 2016, 56, 90-99. [CrossRef]

10. Nonhebel, S. Renewable energy and food supply: Will there be enough land? Renew. Sustain. Energy Rev. 2005, 9, 191-201. [CrossRef]

11. Ravi, S.; Macknick, J.; Lobell, D.; Field, C.; Ganesan, K.; Jain, R.; Elchinger, M.; Stoltenberg, B. Colocation opportunities for large solar infrastructures and agriculture in drylands. Appl. Energy 2016, 165, 383-392. [CrossRef]

12. Dinesh, H.; Pearce, J.M. The potential of agrivoltaic systems. Renew. Sustain. Energy Rev. 2016, 54, 299-308. [CrossRef]

13. Š́ri, M.; Huld, T.A.; Dunlop, E.D. PV-GIS: A web-based solar radiation database for the calculation of PV potential in Europe. Int. J. Sustain. Energy 2005, 24, 55-67. [CrossRef]

14. Pfenninger, S.; Staffell, I. Long-term patterns of European PV output using 30 years of validated hourly reanalysis and satellite data. Energy 2016, 114, 1251-1265. [CrossRef]

15. Hoefnagels, R.; Junginger, M.; Panzer, C.; Resch, G.; Held, A. Long Term Potentials and Costs of RES Part I: Potentials, Diffusion and Technological Learning. Available online: https:/ / dspace.library.uu.nl/handle/1874/235228 (accessed on 10 June 2021).

16. Jacobson, M.Z.; Delucchi, M.A. Providing all global energy with wind, water, and solar power, Part I: Technologies, energy resources, quantities and areas of infrastructure, and materials. Energy Policy 2011, 39, 1154-1169. [CrossRef]

17. Zappa, W.; Junginger, M.; van den Broek, M. Is a 100\% renewable European power system feasible by 2050? Appl. Energy 2019, 233-234, 1027-1050. [CrossRef]

18. Trieb, F.; Schillings, C.; Sullivan, M.O.; Pregger, T.; Hoyer-klick, C. Global Potential of Concentrating Solar Power. In Proceedings of the SolarPaces Conference, Berlin, Germany, 15-18 September 2009; Number September, pp. 1-11. Available online: https:/ / elib.dlr.de/60955/1/Solar_Paces_Paper_Trieb_Final_Colour.pdf (accessed on 10 June 2021).

19. Sun, Y.W.; Hof, A.; Wang, R.; Liu, J.; Lin, Y.J.; Yang, D.W. GIS-based approach for potential analysis of solar PV generation at the regional scale: A case study of Fujian Province. Energy Policy 2013, 58, 248-259. [CrossRef]

20. Bergamasco, L.; Asinari, P. Scalable methodology for the photovoltaic solar energy potential assessment based on available roof surface area: Application to Piedmont Region (Italy). Sol. Energy 2011, 85, 1041-1055. [CrossRef]

21. Zeyringer, M.; Simoes, S.; Mayr, D.; Schmid, E.; Schmidt, J.; Lind, J.; Worrell, E. Solar buildings in Austria: Methodology to assess the potential for optimal PV deployment. In Proceedings of the 2013 10th International Conference on the European Energy Market (EEM), Stockholm, Sweden, 27-31 May 2013; pp. 1-5. [CrossRef]

22. Mainzer, K.; Fath, K.; McKenna, R.; Stengel, J.; Fichtner, W.; Schultmann, F. A high-resolution determination of the technical potential for residential-roof-mounted photovoltaic systems in Germany. Sol. Energy 2014, 105, 715-731. [CrossRef]

23. Brito, M.; Gomes, N.; Santos, T.; Tenedório, J. Photovoltaic potential in a Lisbon suburb using LiDAR data. Sol. Energy 2012, 86, 283-288. [CrossRef]

24. Karteris, M.; Slini, T.; Papadopoulos, A.M. Urban solar energy potential in Greece: A statistical calculation model of suitable built roof areas for photovoltaics. Energy Build. 2013, 62, 459-468. [CrossRef]

25. Lukač, N.; Seme, S.; Žlaus, D.; Štumberger, G.; Žalik, B. Buildings roofs photovoltaic potential assessment based on LiDAR (Light Detection And Ranging) data. Energy 2014, 66, 598-609. [CrossRef]

26. Ghosh, I.; Hellweger, F.L.; Fritch, T.G. Fractal generation of artificial sewer networks for hydrologic simulations. In Proceedings of the 2006 ESRI International User Conference, San Diego, CA, USA, 7-11 August 2006; Number 617; pp. 1-12.

27. Pillai, I.R.; Banerjee, R. Methodology for estimation of potential for solar water heating in a target area. Sol. Energy 2007, 81, 162-172. [CrossRef]

28. Izquierdo, S.; Rodrigues, M.; Fueyo, N. A method for estimating the geographical distribution of the available roof surface area for large-scale photovoltaic energy-potential evaluations. Sol. Energy 2008, 82, 929-939. [CrossRef]

29. Guaita-Pradas, I.; Marques-Perez, I.; Gallego, A.; Segura, B. Analyzing territory for the sustainable development of solar photovoltaic power using GIS databases. Environ. Monit. Assess. 2019, 191, 764. [CrossRef] [PubMed]

30. Schmidt, J.; Schönhart, M.; Biberacher, M.; Guggenberger, T.; Hausl, S.; Kalt, G.; Leduc, S.; Schardinger, I.; Schmid, E. Regional energy autarky: Potentials, costs and consequences for an Austrian region. Energy Policy 2012, 47, 211-221. [CrossRef]

31. Brudermann, T.; Reinsberger, K.; Orthofer, A.; Kislinger, M.; Posch, A. Photovoltaics in agriculture: A case study on decision making of farmers. Energy Policy 2013, 61, 96-103. [CrossRef]

32. Simoes, S.; Zeyringer, M.; Mayr, D.; Huld, T.; Nijs, W.; Schmidt, J. Impact of different levels of geographical disaggregation of wind and PV electricity generation in large energy system models: A case study for Austria. Renew. Energy 2017, 105, 183-198. [CrossRef]

33. Defaix, P.R.; van Sark, W.G.; Worrell, E.; de Visser, E. Technical potential for photovoltaics on buildings in the EU-27. Sol. Energy 2012, 86, 2644-2653. [CrossRef]

34. Seidl, R. Photovoltaik-Ausbaupotential im Versorgungsgebiet Wien Netz-Plausibilitätscheck, Endergebnisse; Technical Report; ÖIR: Austrian Institute for Regional Studies; Austria and Austrian Institute for Regional Studies: Vienna, Austria, 2018.

35. Kjellsson, E. Potential for building integrated photovoltaics. IEA PVPS Task 2002, 2002, 4. 
36. Streicher, W.; Schnitzer, H.; Heimrath, R.; Titz, M. Energieautarkie für Österreich 2050. 2010. Available online: https://www. klimafonds.gv.at/wp-content/uploads/sites/16/Energieautarkie205012pt20110308Final.pdf (accessed on 10 October 2020)

37. Huld, T.; Müller, R.; Gambardella, A. A new solar radiation database for estimating PV performance in Europe and Africa. Sol. Energy 2012, 86, 1803-1815. [CrossRef]

38. Agrarmarkt Austria. INVEKOS Schläge Österreich. 2018. Available online: https://www.data.gv.at/katalog/dataset/f7691988 -e57c-4ee9-bbd0-e361d3811641 (accessed on 10 October 2020)

39. Umweltbundesamt; Sentinel-2 Bodenbedeckung Österreich: Vienna, Austria, 2016.

40. Conrad, O.; Bechtel, B.; Bock, M.; Dietrich, H.; Fischer, E.; Gerlitz, L.; Wehberg, J.; Wichmann, V.; Böhner, J. System for Automated Geoscientific Analyses (SAGA) v. 2.1.4. Geosci. Model Dev. 2015, 8, 1991-2007. [CrossRef]

41. Geoland.at. Digital Terrain Model of Austria, Based on Airborne Laserscanning. Available online: https://www.data.gv.at/ auftritte / ?organisation=geoland (accessed on 20 June 2020)

42. Krutzler, T.; Wiesenberger, H.; Heller, C.; Gössl, M.; Stranner, G.; Storch, A.; Heinfellner, H.; Winter, R.; Kellner, M.; Schindler, I. Szenario Erneuerbare Energie 2030 und 2050; Technical report; Umweltbundesamt Österreich: Vienna, Austria, 2016.

43. Veigl, A. Energie- und Klimazukunft österreich Szenario für 2030 und 2050; Technical Report, Global 2000; Greenpeace und WWF: Vienna, Austria, 2017.

44. Auer, H.; Crespo del Granado, P.; Oei, P.Y.; Hainsch, K.; Löffler, K.; Burandt, T.; Huppmann, D.; Grabaak, I. Development and modelling of different decarbonization scenarios of the European energy system until 2050 as a contribution to achieving the ambitious $1.5^{\circ} \mathrm{C}$ climate target -establishment of open source/data modelling in the European H2020 project openENT. Elektrotechnik Informationstechnik 2020, 137, 346-358. [CrossRef]

45. Jacobson, M.Z.; Delucchi, M.A.; Bauer, Z.A.; Goodman, S.C.; Chapman, W.E.; Cameron, M.A.; Bozonnat, C.; Chobadi, L.; Clonts, H.A.; Enevoldsen, P.; et al. 100\% Clean and Renewable Wind, Water, and Sunlight All-Sector Energy Roadmaps for 139 Countries of the World. Joule 2017, 1, 108-121. [CrossRef]

46. The Federal Republic of Germany; The French Republic; The Italian Republic; The Republic of Slovenia; The Principality of Liechtenstein; The Republic of Austria; The Swiss Federation.; The European Economic Community. Convention on the protection of the Alps (Alpine Convention). Off. J. Eur. Communities 1996. Available online: http://data.europa.eu/eli/ convention/1996/191/oj (accessed on 10 June 2021).

47. Biermayr, P.; Dißauer, C.; Eberl, M.; Enigl, M.; Leonhartsberger, K.; Maringer, F.; Moidl, S.; Schmidl, C.; Strasser, C.; Weiss, W.; Wonisch, P.; et al. Innovative Energietechnologien in Österreich - Marktentwicklung 2019, Biomasse, Photovoltaik, Solarthermie, Wärmepumpen und Windkraft. In Berichte aus Energie-und Umweltforschung; Im Auftrag des Bundesministerium für Wissenschaft und Verkehr 100 Seiten: Klagenfurt, Austria, 2020; pp. 1-266.

48. Mikovits, C. Rooftop and open space PV data for Austria. Zenodo 2021. [CrossRef]

49. Hertel, T.W.; Lobell, D.B. Agricultural adaptation to climate change in rich and poor countries: Current modeling practice and potential for empirical contributions. Energy Econ. 2014, 46, 562-575. [CrossRef]

50. IPCC. IPCC, 2014: Climate Change 2014: Synthesis Report. Contribution of Working Groups I, II and III to the Fifth Assessment Report of the Intergovernmental Panel on Climate Change; Technical Report; IPCC: Geneva, Switzerland, 2014.

51. Karpić, J.; Sharma, E.; Khatib, T.; Elmenreich, W. Comparison of solar power measurements in alpine areas using a mobile dual-axis tracking system. Energy Informatics 2019, 2, 23. [CrossRef]

52. Michel, A.H.; Buchecker, M.; Backhaus, N. Renewable Energy, Authenticity, and Tourism: Social Acceptance of Photovoltaic Installations in a Swiss Alpine Region. Mt. Res. Dev. 2015, 35, 161-170. [CrossRef]

53. Hastik, R.; Basso, S.; Geitner, C.; Haida, C.; Poljanec, A.; Portaccio, A.; Vrščaj, B.; Walzer, C. Renewable energies and ecosystem service impacts. Renew. Sustain. Energy Rev. 2015, 48, 608-623. [CrossRef]

54. Jackson, A.L. Renewable energy vs. biodiversity: Policy conflicts and the future of nature conservation. Glob. Environ. Chang. 2011, 21, 1195-1208. [CrossRef]

55. Száz, D.; Mihályi, D.; Farkas, A.; Egri, A.; Barta, A.; Kriska, G.; Robertson, B.; Horváth, G. Polarized light pollution of matte solar panels: anti-reflective photovoltaics reduce polarized light pollution but benefit only some aquatic insects. J. Insect Conserv. 2016, 20, 663-675. [CrossRef]

56. Fthenakis, V.; Blunden, J.; Green, T.; Krueger, L.; Turney, D. Large photovoltaic power plants: Wildlife impacts and benefits. In Proceedings of the 2011 37th IEEE Photovoltaic Specialists Conference, Seattle, WA, USA, 19-24 June 2011; pp. $2011-2016$. [CrossRef] 